\title{
HHIP Gene
}

National Cancer Institute

\section{Source}

National Cancer Institute. HHIP Gene. NCI Thesaurus. Code C127009.

This gene plays a role in hedgehog signaling pathways. 